\title{
В.И. Габдуллина
}

Барнаульский государственный педагогический университет

\section{Семиотика жеста в поэтической системе Ф.М. Достоевского: сакральное и профанное}

Аннотация: В статье рассматриваются особенности функционирования в поэтической системе романов Ф.М. Достоевского «Преступление и наказание» и «Братья Карамазовы» жестов поклона и поцелуя, за которыми бытовая и древняя ритуально-обрядовая традиции закрепили определенные символические значения. Посредством изображения этих жестов автор сталкивает в поведении героев норму (восходящую к сакральному началу) и ее нравственное искажение. Жест земного поклона как элемент акта покаяния является в произведениях Достоевского высшим проявлением духовного единения человека и Бога.

Ключевые слова: семиотика, поэтика, жест, творчество Ф.М. Достоевского.

Поэтика жеста приобретает особое значение в художественной структуре романа-трагедии, созданного Ф.М. Достоевским, поскольку по законам драмы «все внутреннее должно быть обнаружено в действии» [Иванов, 1990, с. 173]. В силу того что действие романов Достоевского развивается «сразу в нескольких планах бытия» [Гессен, 1990, с. 351], жест у Достоевского приобретает полисемантическое и знаковое значение: это не просто фиксация внешнего движения как передача душевных переживаний и психологических состояний персонажа (план эмпирический), но и знак или форма его отношения к миру действительному и идеальному (план символический). Как в связи с этим замечает Р.Г. Назиров: «Бытовое поведение героев Достоевского часто имеет символический характер: писатель рисует поведение как высказывание» [Назиров, 2005, с. 125]. В условиях полифонической системы романа Достоевского жест выполняет функцию высказывания не только и не столько героя, сколько автора о герое: его психологическом состоянии, характере, отношении к миру.

Внимательный читатель не может не заметить, что из романа в роман у Достоевского переходят жесты, к которым писатель испытывает особое пристрастие в силу их многозначности и заложенных в них психологических и символических возможностей. Это в первую очередь относится к жестам поклона и поцелуя, за которыми бытовая культурная и древняя ритуально-обрядовая традиция закрепила определенные символические значения. Жесты поклона и поцелуя в романах Достоевского характеризуют психологическое поведение героев, а также являются знаками степени принадлежности персонажей к высшей духовной сфере жизни, своеобразными медиаторами, переводящими действие в метафизический план.

В романе «Преступление и наказание», открывающем «великое пятикнижие» Достоевского, жестам поклона и поцелуя автор отводит особое место, подчеркивая и объясняя их символический смысл. Так, символика поклона Раскольникова Соне («он весь быстро наклонился и, припав к полу, поцеловал ее ногу» [Достоевский, 1973, т. 6, с. 246]) объяснена самим героем: «Я не тебе поклонился, а всему страданию человеческому поклонился...» [Там же]. Соня, в 
свою очередь, говорит Раскольникову о необходимости покаяния, объясняя ритуальное значение земного поклона: «Поди сейчас, сию же минуту, стань на перекрестке, поклонись, поцелуй сначала землю, которую ты осквернил, а потом поклонись всему свету, на все четыре стороны, и скажи всем вслух: “Я убил!” Тогда бог опять тебе жизнь пошлет» [Достоевский, 1973, т. 6, с. 322]. В данном случае имеет значение и место совершения ритуального жеста. Как отмечено в литературоведении: «Перекресток есть крест, который Раскольников должен взять на себя» [Бражников, 2002, с. 34], [Тихомиров, 2005, с. 340-341].

Покаянный жест Раскольникова, который он совершает, почти механически выполняя то, что велела ему Соня, неожиданно потряс его до глубины души: «...Когда он дошел до средины площади, с ним вдруг произошло одно движение, одно ощущение овладело им сразу, захватило его всего - с телом и мыслию. $<\ldots>$ Он стал на колени среди площади, поклонился до земли и поцеловал эту грязную землю, с наслаждением и счастьем» [Достоевский, 1973, т. 6, с. 405]. И хотя Раскольников не выдержал до конца этого испытания (преображения через покаяние не произошло из-за вновь проснувшегося в его душе презрения к людям), чувства, которые он ощутил в себе в этот момент, - знак возможности его будущего воскресения. В Раскольникове это «движение» происходит внезапно, «вдруг», но оно стало исходом его страдания, внутренней потребностью его души. Причастной к покаянию Раскольникова автор делает не только Соню, но и «нищую бабу с ребенком», которой он по дороге на площадь подал пятак, и услышал от нее: «Сохрани тебя бог!» [Достоевский, 1973, т. 6, с. 405]. «Нищая баба с ребенком», благословившая Раскольникова, и «погорелая баба с дитем», явившаяся Дмитрию Карамазову в его пророческом сне накануне его покаяния, очевидно, связаны в авторском сознании с образом Богородицы - заступницы за грешников перед Богом, которая в православной традиции ассоциируется матерью сырой землей. Мария Лебядкина в «Бесах» рассказывает, что после поучения старицы, которая открыла ей, что «Богородица - великая мать сыра земля, и великая в том для человека заключается радость. $<\ldots>$ А как напоишь слезами своими под собой землю на пол-аршина в глубину, то тотчас же о всем и возрадуешься», стала «с тех пор на молитве, творя земной поклон, каждый раз землю целовать...» [Достоевский, 1974, т. 10, с. 116]. Таким образом, земной поклон и поцелуй земли, по Достоевскому, - высшее проявление единения человека с миром, преклонения перед Богородицей, символ смирения перед Богом, признание его законов. Наивысшей точки символического звучания достигает изображение жеста земного поклона в сцене духовного просветления Алеши Карамазова: «Алеша стоял, смотрел и вдруг как подкошенный повергся на землю. <..> он целовал ее плача, рыдая и обливая своими слезами...» [Достоевский, 1976, т. 14, с. 328].

Сцена покаяния Раскольникова в эпилоге романа изображена посредством жестового поведения; автор фиксирует внимание на двух жестах - рукопожатия и коленопреклонения. Изменение душевного состояния Раскольникова после его болезни, которая совпала со Страстной неделей и Святой - временем смертных страданий и воскресения Христа - проявилось в том, как он пожимает руку Сони: «Она всегда протягивала ему свою руку робко, иногда даже не подавала совсем, как бы боялась, что он оттолкнет ее. Он всегда как бы с отвращением брал ее руку... <..> Но теперь их руки не разнимались...» [Достоевский, 1973, т. 6, с. 421]. С точки зрения С.Б. Пухачева, исследовавшего поэтику жеста в произведениях Достоевского, «рукопожатие или соприкосновение рук» принадлежит к сакральным жестам и символизирует, с одной стороны, «установление горизонтальных связей между людьми», с другой, - «возврат к Творению» («подобно изображенному на фреске Микеланжело “Сотворение Адама”») [Пухачев, 2006, с. 18.]. Согласно логике исследователя, в иерархии жестов в произведениях Достоевского, рукопожатие - высший жест, в отличие от поклона и поцелуя, как бы «затертых» от частого бытового употребления и утративших свое высшее значение, и посему 
не могущих «претендовать на “скрепу”, объединяющую героев романа» [Пухачев, 2007$, c. 480$]$. Однако, если судить по финалу романа «Преступление и наказание», поклону или коленопреклонению автор придавал не меньшее значение как жесту, маркирующему состояние преображения героя. Именно посредством этого жеста автор изображает покаяние Раскольникова («Он плакал и обнимал ее колени»), предшествующее его воскресению («Но он воскрес, и он знал это, чувствовал всем обновившимся существом своим» [Достоевский, 1973, т. 6, с. 421]). Поза Раскольникова, стоящего на коленях перед Соней, воспринимается как покаянный жест, отсылающий к традиционным изображениям финального эпизода притчи о блудном сыне (на известной картине Рембранта «Возвращение блудного сына», и на лубочных картинках, иллюстрирующих притчу). Таким образом, при помощи рисунка жестового поведения персонажей автор встраивает финальную сцену романа посредством включения читательских ассоциаций в евангельский контекст, проецируя сакральный смысл на историю преступления и покаяния Раскольникова.

Жесты поклона и поцелуя в их сакральном и профаном значении выступают как важнейшие элементы поэтики последнего романа Достоевского «Братья Карамазовы». Безусловно, одним из самых загадочных является в романе поцелуй Христа в финале поэмы о Великом инквизиторе. Исповедь инквизитора - это не исповедь-покаяние («Поцелуй горит на его сердце, но старик остается в прежней идее» [Достоевский, 1976, т. 14, с. 239]), поэтому этот жест Христа, очевидно, не может трактоваться как отпущение грехов. Поцелуй в христианском ритуале имеет и другое значение - это символ принятия на себя чужого страдания как знак единения и любви. «Поцелуй Христа подчеркивает в поэме милосердие и высоту самого Христа, не оставляющего своей любовью даже этого мрачного убийцу. Поцелуй отличает “божие” и в душах тех, кто проповедует “безбожие”» [Ветловская, 1977, с. 125]. Именно через единение, по Достоевскому, лежит путь к достижению мира и гармонии, только любовью можно возродить душу.

Поразительно, что «автор» сцены с поцелуем Христа - Иван Карамазов, разуверившийся в идее христианской любви. Создается впечатление, что сам автор поэмы об инквизиторе не до конца понимает смысл этого жеста Христа, доступный его слушателю - Алеше. Выслушав «поэмку» Ивана, Алеша встал, подошел к нему и молча тихо поцеловал его в губы. Поцелуй Алеши, повторившего жест Христа, явился своеобразным ответом на те неразрешимые вопросы, которые мучили сердце Ивана, проясняя в то же время смысл жеста Христа для самого создателя «поэмы». Алеша увидел в сердце брата борьбу любви с презрением к людям. Поцелуй Алеши должен был поддержать в Иване начало любви, спасти его сердце от «бесовщины». Неслучайно после этого поцелуя Иван «признается в любви» Алеше: «Довольно мне того, что ты тут где-то есть, и жить еще не расхочу... Если хочешь, прими хоть за объяснение в любви» [Достоевский, 1976, т. 14, с. 240]. Перед самым расставанием Иван просит Алешу еще раз поцеловать его, у него является потребность еще раз ощутить чувство братской любви. Однако, как и герой его поэмы, Иван «остается в прежней идее».

Еще до разговора Ивана с Алешей старец Зосима, поняв «муку» Ивана, благословил его словами: «Дай вам бог, чтобы решение сердца вашего постигло вас еще на земле, и да благословит бог пути ваши!» [Достоевский, 1976, т. 14, с. 66]. Принимая благословение старца, Иван «поцеловал его руку», совершая тем самым ритуал, но очевидно, что для Ивана это не простое соблюдение правила. Этим поцелуем руки старца Иван приготовился на муки сердца, принял богом данное испытание.

В поэме о великом инквизиторе жесты поклона и поцелуя выступают как в своем высшем сакральном значении, так и в «стертой» ритуалом форме. В начале поэмы явившийся людям Христос «простирает к ним руки, благословляя их». В порыве любви «народ плачет и целует землю, по которой идет он» [Достоевский, 
1976, т. 14, с. 227]. Это «целование земли» как выражение любви и благодарности Христу противопоставлено в поэме преклонению перед инквизитором. Он тоже благословляет людей, но это благословение лишено любви, это требование покорности: «Толпа моментально, вся как один человек, склоняется головами до земли перед старцем инквизитором, тот молча благословляет народ и проходит мимо» [Достоевский, 1976, т. 14, с. 227]. Если в общении Христа с народом подчеркивается их духовный контакт, то между инквизитором и «толпой» устанавливаются другие отношения, основанные на власти, с одной стороны, и покорности, с другой. Оппозиция жестов: поцелуй и поклон любви / склонение головы как знак покорности - символизирует две формы мироустройства, о которых идет речь в поэме Ивана.

Символическим значением не исчерпываются функции жестов поклона и поцелуя в тексте последнего романа «великого пятикнижия», так как наряду с сакральным эти жесты имеют и профанный смысл. В келье старца Зосимы (книга вторая «Неуместное собрание») совершается ряд поклонов присутствующими в этой келье героями. Поклон в церковном ритуале является символическим действием, которое служит выражением величайшего смирения перед Богом и особенной теплоты молитвы, поклоном сопровождается обряд благословения. П. Флоренский связывал поклон с ритуалом покаяния, без которого нет воскресения, замечая, что «кладя поклоны, мы учимся воскресению» [Флоренский, 2004, c. 340]. В романе можно наблюдать, как поклон из сакрализованного ритуального жеста превращается под пером писателя в средство психологической характеристики персонажей, сигнализируя об искажении их духовной сущности.

Собственно ритуальными можно считать в сцене в келье только жесты иеромонахов и Зосимы, которые, благословляя друг друга, совершают обмен глубокими поклонами. Причем рассказчик замечает, что «вся церемония произошла весьма серьезно, вовсе не как вседневный обряд какой-нибудь, а почти с каким-то чувством» [Достоевский, 1976, т. 14, с. 36] (курсив наш. - В.Г.). Присутствующие в келье по-разному интерпретируют этот ритуал. Для Миусова, поклониться в ноги и принять благословение старца «несмотря ни на какие идеи» представляется жестом «простой вежливости (так как уж здесь такие обычаи)». Но и от него он отказывается, «увидя теперь все эти поклоны и лобызания иеромонахов», которые показались ему сделанными «с намеренным внушением». Поэтому «он в одну секунду переменил решение: важно и серьезно отдал он довольно глубокий, посветскому, поклон и отошел к стулу» [Достоевский, 1976, т. 14, с. 36]. Неуместность этого жеста в келье старца тут же была спародирована в шутовском поклоне Федора Павловича: «Точно так же поступил и Федор Павлович, на этот раз как обезьяна совершенно передразнив Миусова». Поклон Ивана Федоровича, который «раскланялся очень важно и вежливо, но тоже держа руки по швам» (т.е. тоже «по-светскому»), окончательно привел в такое замешательство еще одного участника этой церемонии - Калганова, что он «до того сконфузился, что и совсем не поклонился» («вежливость» Ивана в этой ситуации равноценна отсутствию ее в поступке Калганова). Несмотря на это старец «поклонился им в другой раз», завершая несостоявшийся ритуал благословения («опустил поднявшуюся было для благословения руку») [Там же].

Если в жесте Миусова и Ивана проявляется «намеренность» (Миусов «даже обдумывал это еще вчера вечером»), а у Федора Павловича даже «злонамеренность», то Дмитрий - единственный, кем в келье Зосимы движет искреннее чувство: «Он глубоко поклонился ему и попросил благословения. Старец, привстав, благословил его; Дмитрий Федорович почтительно поцеловал его руку ...» [Достоевский, 1976, т. 14, с. 63]. Искренность второго «надуманного» «почтительного» и «глубокого» поклона Дмитрия Федоровича своему «батюшке» рассказчик оговаривает отдельно, сообщая, что этот поклон герой обдумал «заранее и надумал его искренно, почтя своею обязанностью выразить тем свою почтительность 
и добрые намерения» по отношению к своему «родителю» [Достоевский, 1976, т. 14, с. 64].

Символичен поклон здесь же в келье старца Зосимы «будущему страданию» Дмитрия: «Став на колени, старец поклонился Дмитрию Федоровичу в ноги, полным, отчетливым, сознательным поклоном и даже лбом своим коснулся земли» (Достоевский, 1976, т. 14, с. 69). Этот пророческий жест остается загадкой для всех присутствующих при этой сцене, и смысл его раскрывается постепенно. Вначале через историю самого старца Зосимы (Книга шестая. «Русский инок»), после знакомства с которой в восприятии читателя сопрягаются судьбы Зосимы и Дмитрия; затем в девятой книге романа, когда Митя неожиданно заявляет: «Принимаю муку обвинения и всенародного позора моего, пострадать хочу и страданием очищусь!» [Достоевский, 1976, т. 14, с. 458]. Поклон старца Зосимы сыграл, таким образом, роль предопределения в судьбе Дмитрия Карамазова.

Итак, уже в сцене в келье Зосимы поклон представлен, с одной стороны, как церковный ритуал, совершаемый «серьезно» и «с глубоким чувством», с другой стороны, ему противопоставлен светский поклон «из вежливости» героев, утративших веру не только в обрядовую сторону религии, но и в ее духовное начало. Особенное значение придается поклону и в бытовом поведении героев. Принятое в обиходе выражение «откланяться», обозначающее жест при прощании, приобретает в романе глубокое психологическое значение.

Взаимоотношения Дмитрия и Катерины Ивановны в романе сопровождаются целой серией поклонов. Не приняв добровольную жертву Катерины Ивановны в обмен на необходимые ей для спасения чести отца деньги, Дмитрий, провожая, «поклонился ей в пояс почтительнейшим, проникновеннейшим поклоном». Для Катерины Ивановны этот поклон означал не только прощальный жест, великодушие Дмитрия поразило ее до глубины души. Гамма чувств, переживаемая героиней в эту минуту, проявилась в ее ответном жесте, о котором Дмитрий рассказывает Алеше: «Она вся вздрогнула, посмотрела пристально секунду, страшно побледнела, ну как скатерть, и вдруг, тоже ни слова не говоря, не с порывом, а мягко так, глубоко, тихо, склонилась вся и прямо мне в ноги - лбом до земли, не поинститутски, по-русски!» [Достоевский, 1976, т. 14, с. 106]. Митя с восторгом говорит об искреннем «русском» поклоне Катерины Ивановны, сама же она скажет об этом поклоне на суде: «...я ему тогда в ноги за эти деньги поклонилась» [Достоевский, 1976, т. 15, с. 120], уверенная, что Митя должен был презирать ее за это. Рассказчик так пишет об этом эпизоде: «Нет, нет, она не клеветала намеренно, крича, что Митя презирал ее за земной поклон! Она сама верила в это, она была глубоко убеждена, с самого, может быть, этого поклона, что простодушный, обожавший ее тогда Митя смеется над ней и презирает ее» [Достоевский, 1976, т. 15, c. 121-122].

Память об этом поклоне звучит в словах Мити, отправляющего Алешу к Катерине Ивановне с поручением: «Сказать ей, что я больше к ней не приду никогда, приказал, дескать, кланяться» [Достоевский, 1976, т. 14, с. 109]. Причем последнюю фразу он повторяет несколько раз («Велел вам кланяться», «Велел, дескать, кланяться»). Катерина Ивановна очень точно уловила значение этого жестапослания, угадав за ним психологическое состояние Мити, решившегося при прощании напомнить ей о «том поклоне». В этой череде обменов поклонами отразились перипетии развития любви-ненависти между Дмитрием и Катериной Ивановной, завершившиеся в последнем свидании героев странным жестом то ли поцелуя, то ли поклона: она «жадно приникла устами к руке его» [Достоевский, 1976 , т. 15 , с. 187$]$.

Как видим, жесты поклона и поцелуя сопровождают наиболее драматически напряженные сцены романов Достоевского, способствуя их зрительнопластическому восприятию читателем. Вместе с тем, они являются мощным средством психологической характеристики персонажей в связи с традиционно закре- 
пленным за этими жестами нравственно-этическим значением. В авторской трактовке поклона и поцелуя обнаруживается определенная закономерность: автор посредством изображения этих жестов сталкивает в поведении героев норму (восходящую к сакральному началу) и ее нравственное искажение. Высшим проявлением духовного единения человека и Бога является в произведениях Достоевского жест земного поклона - необходимый элемент акта покаяния, единственного, по мнению писателя, исхода «русского бездомного скитальца».

\section{Литература}

Бражников И. Внутри и снаружи. Истинный миропорядок в романе «Преступление и наказание» // Достоевский и мировая культура. Альманах № 17. М., 2002.

Ветловская В.Е. Поэтика романа «Братья Карамазовы». Л., 1977.

Гессен С.И. Трагедия добра в «Братьях Карамазовых» Достоевского // Творчество Достоевского в русской мысли 1881 - 1931 годов. М., 1990.

Достоевский Ф.М. Полн. собр. соч.: В 30 т. Л., 1972-1990.

Иванов Вяч.И. Достоевский и роман-трагедия // Творчество Достоевского в русской мысли 1881 - 1831 годов. М.,1990.

Касаткина Т.А. О творящей природе слова. Онтологичность слова в творчестве Ф.М. Достоевского как основа «реализма в высшем смысле». М., 2004.

Назиров Р.Г. Жесты милосердия в романах Достоевского // Русская классическая литература: сравнительно-исторический подход. Исследования разных лет Сборник статей. Уфа, 2005.

Пухачев С.Б. Поэтика жеста в произведениях Ф.М. Достоевского (на материале романов «Преступление и наказание», «Идиот», «Бесы», «Подросток», «Братья Карамазовы»): Автореф. дис. ... канд. филол. наук. Великий Новгород, 2006.

Пухачев С.Б. Кинестетические наблюдения над романом Ф.М. Достоевского «Братья Карамазовы» // Роман Ф.М. Достоевского «Братья Карамазовы»: современное состояние изучения. М., 2007.

Тихомиров Б.Н. «Лазарь! Гряди вон». Роман Ф.М. Достоевского «Преступление и наказание» в современном прочтении. Книга-комментарий. СПб., 2005.

Флоренский П.А. Собр. соч. Философское наследие. М., 2004. Т. 13. 